\title{
The Analysis of Climate Change Awareness at Local Level
}

\author{
Burçin Atılgan Türkmen ${ }^{1 *}$ \\ 1* Bilecik Seyh Edebali University, Faculty of Engineering, Departmant of Chemical Engineering, Bilecik, Turkey, (ORCID: 0000-0003-3220-3817), \\ burcin.atilganturkmen@bilecik.edu.tr
}

(First received 4 March 2021 and in final form 26 June 2021)

(DOI: 10.31590/ejosat.890865)

ATIF/REFERENCE: Atilgan Turkmen, B., (2021). The Analysis of Climate Change Awareness at Local Level. European Journal of Science and Technology, (25), 457-462.

\begin{abstract}
Climate change is one of the biggest problems facing the world today due to its negative effects on human health and ecosystems. It is important to evaluate society's awareness of climate change to avoid this problem. Understanding the drivers of climate change attitudes is critical, as an action to address climate change is dependent on public awareness. Therefore, this research was carried out to identify the level of awareness and knowledge of climate change of residents in the province of Bilecik. In order to collect data, a questionnaire consisting of 11 questions was applied to randomly selected 508 people. Statistical approaches have been used to test the data collected from questionnaires. According to the results of the research, of the respondents $96 \%$ stated that they believe that climate change is occurring, $89 \%$ stated that climate change is occurring in Bilecik, of the respondents $87 \%$ believe that climate change is threatening. The majority of respondents $(83 \%)$ believe that increasing the number of vehicles is the primary cause of climate change, while changes in climate types $(89 \%)$ are the most visible effect of climate change. The results revealed that the issue of climate change was acknowledged at the local level, that there would be a tendency to change the lifestyle of the situation, and that they wanted to get more education on the subject.
\end{abstract}

Keywords: Awareness, Climate change, Bilecik, Public perception, Adaptation.

\section{İklim Değişikliği Bilincinin Yerel Düzeyde Analizi}

$\ddot{O z}$

İklim değişikliği, insan sağlığı ve ekosistemler üzerindeki olumsuz etkileri nedeniyle bugün dünyanın karşılaştığı en büyük sorunlardan biridir. Bu sorunu önlemek için toplumun iklim değişikliği konusundaki farkındalığını değerlendirmek önemlidir. İklim değişikliği eylemi halkın bilincine bağlı olduğundan, iklim değişikliğinin itici güçlerini anlamak çok önemlidir. Bu nedenle, bu araştırma Bilecik ilinde ikamet edenlerin iklim değişikliği konusundaki farkındalık ve bilgi düzeylerini belirlemek amacıyla yapılmıştır. Veri toplamak için rastgele seçilen 508 kişiye 11 sorudan oluşan bir anket uygulanmıştr. Anketlerden toplanan verileri test etmek için istatistiksel yaklaşımlar kullanılmıştır. Elde edilen sonuçlar, ankete katılanların \%96'sı iklim değişikliğinin meydana geldiğine, \%89'u Bilecik'te iklim değişikliğinin meydana geldiğine, \%87'si iklim değişikliğinin tehdit edici olduğuna inandığın belirtmiştir. Ankete katılanların çoğunluğu (\%83) araç sayısındaki artışın iklim değişikliğinin temel nedeni olduğunu, iklim tiplerindeki değişikliklerin (\%89) iklim değişikliğinin en belirgin etkisi olduğu sonucu elde edilmiştir. Sonuçlar, iklim değişikliği konusunun yerel düzeyde kabul edildiğini, ankete katılanların yaşam tarzını değiştirme eğiliminde olduğunu ve konuyla ilgili daha fazla eğitim almak istediklerini ortaya koymuştur.

Anahtar Kelimeler: Bilinç, İklim değişikliği, Bilecik, Kamuoyu algısı, Uyum.

\footnotetext{
* Corresponding Author: burcin.atilganturkmen@bilecik.edu.tr
} 


\section{Introduction}

Climate change is one of the $21^{\text {st }}$ century's greatest challenges. It is defined by United Nations Framework Convention on Climate Change (UNFCCC) as describes a change in climate that is due directly or indirectly to human activity that alters the composition of the global atmosphere, in addition to normal climate variations observed over comparable periods (UNFCCC, 1992).

The climate of the earth has been continuously changing over time, with wide differences in global average temperatures. However, this current warming period is happening more dramatically than any previous event (Allen, 2018). UNFCCC reveals that the observed increases in greenhouse gas emissions because of human activities are the major cause of global climate change. After the industrial revolution, humans have released greenhouse gasses into the atmosphere, altering the atmospheric balance of the earth. These gasses continue to accumulate in the atmosphere and the ocean today. According to the Intergovernmental Panel on Climate Change (IPCC), an increase of $1.5^{\circ} \mathrm{C}$ in global average temperature is a limit beyond which climate change will have devastating consequences (UN, 2020).

Climate change is a global problem that in various ways impacts countries. In several countries, the impacts of climate change have already reached many of the major sectors of production and development (Glasgow et al., 2018). The Mediterranean Basin, including Turkey, is one of the most sensitive regions of the earth to global climate change. The effects of the $2{ }^{\circ} \mathrm{C}$ increase in temperature, unexpected weather events, heat waves, increase in the number and impact of forest fires, drought and, consequently, loss of biodiversity, decrease in tourism revenues, loss of agricultural yield, and, most importantly, drought will be felt (Cramer W, 2018).

Climate change is one of humanity's most important challenges which seriously threatens our future unless action is taken today. For this reason, immediate global, regional and local action needs to be taken and collaboration should be improved in the fight against climate change (MoEU, 2018). In order to reduce greenhouse gasses emitted into the atmosphere, both individuals and countries have important responsibilities. The levels of climate change understanding, awareness, perceived risk, and support for mitigation or adaptation differ widely around the world (Lee et al., 2015). The key measure to be taken is to change the lifestyles and consumption patterns of societies. For individual habits to change, this issue needs to be more sensitive and more conscious. Awareness of climate change can be described as potential concerns about threats from climate change to human society and the natural environment. Knowledge of climate change is essential for implementing successful initiatives to mitigate the risks of climate change (Kim \& Hall, 2019; Marshall et al., 2013).

The objective of Turkey is to reduce the impact of climate change and to respond to global warming. The level of public awareness and institutional capacity must be considered when adapting to climate change in the country. Education, public awareness-raising studies, and international cooperation on climate change began when Turkey became a party UNFCCC in 2004 and accelerated following the publication of the country's First National Communication on Climate Change in 2007 (MoEU, 2012). Climate Change National Action Plan (20112023) released in July 2011 on the implementation of the Climate
Change National Strategy Document includes measures to coordinate institutional capacity building and awareness-raising programs to combat and adapt (MoEU, 2018). Science and policy debates on climate change should be rooted in an increased understanding of public awareness (Dal et al., 2015). A basic understanding of public knowledge of climate change will provide strategic guidance for government policy, adaptation and mitigation plans, and community-based guidance (Kabir et al., 2016).

This study aims to determine the perception and awareness level of residents' understanding, knowledge, and concern of climate change. Bilecik province in Turkey was chosen as the study area. Appropriate statistical techniques have been used to gather and analyze relevant information using the questionnaire approach.

\section{Material and Method}

\subsection{Study Area}

Climate change, both nationally and globally, has been one of the most debated environmental issues. This paper was therefore conducted to identify the current level of awareness and knowledge of climate change of residents in the province of Bilecik.

Bilecik is positioned in four regions - Marmara, Black Sea, Aegean, and Central Anatolian regions. It has an area of 4,307 $\mathrm{km}^{2}$, and a population of 219,427 people as of 2019 (TURKSTAT, 2020). The province is located between $39^{\circ} 39^{\prime}$ and $40^{\circ} 31^{\prime}$ latitudes to the north and $29^{\circ} 43^{\prime}$ and $30^{\circ} 40^{\prime}$ longitudes to the east. Bilecik is an alternate city at the point where the Marmara area is linked to Anatolia. As presented in Figure 1, it is bordered by the provinces of Eskisehir and Bolu to the east, Kütahya to the south, Bursa to the west, and Sakarya to the north. Agriculture and animal husbandry, mining, forestry, marble, ceramics, and board processing have a significant part of the province's economy. The rich marble quarries in Bilecik have made a significant contribution to the economy of the city (BEBKA, 2018).

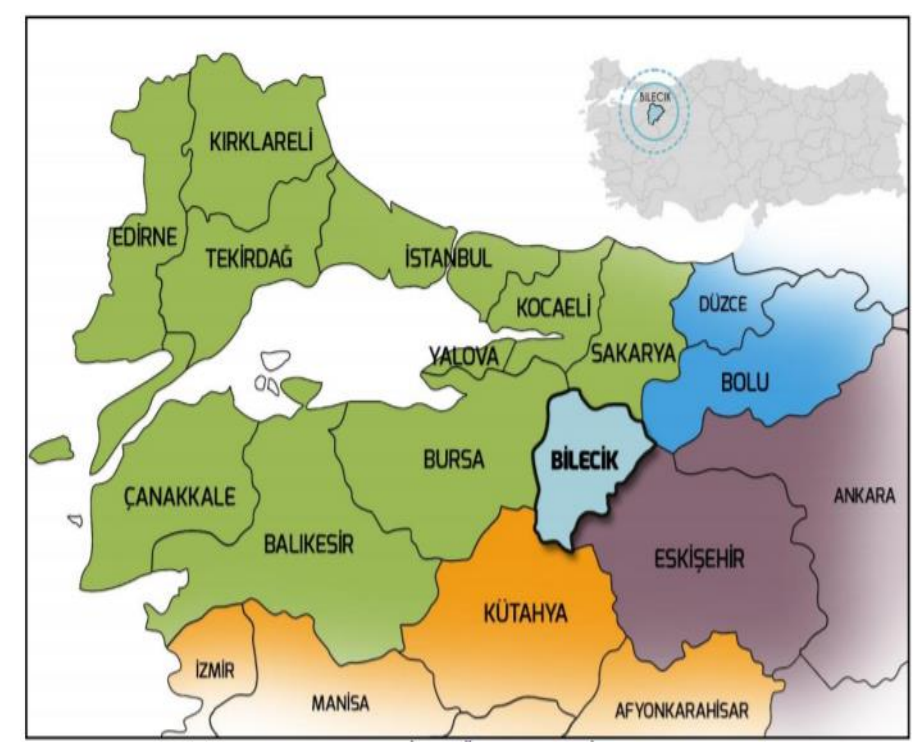

Figure 1: Location of the study area (BEBKA, 2018)

Bilecik is expected to grow in the future and the surrounding forest and agricultural land are expected to decrease due to 
transport and industrial investment. In this process, in addition to industry, greenhouse gas emissions from construction will increase as a consequence of the loss of natural areas and the intensification of urbanization (Governorate of Bilecik, 2020).

\subsection{Data}

The data used in this study is primary data collected by a survey of 508 people in the province of Bilecik, Turkey. The survey was carried out in 2018. A face-to-face interview with the respondents was conducted, where they were chosen through random stratified sampling. The purpose of the survey and when needed the words used in the survey have been clarified to the respondents and kept confidential.

\section{Results and Discussion}

A total of 508 randomly selected survey respondents were interviewed face to face in the survey to assess the current level of awareness of climate change in the province of Bilecik. Statistical approaches have been used to test the data collected from questionnaires. The statistical analysis was performed using SPSS Statistics Base 22.0 package program.

As shown in Table 1, 262 survey respondents (nearly 51.6\% more than half of those surveyed) were female and showed a slight gender balance.

\section{Table 1: Gender Distribution of Respondents}

\begin{tabular}{lrr}
\hline Gender & Respondents & Percentage (\%) \\
\hline Female & 262 & 51.57 \\
Male & 246 & 48.43 \\
\hline Total & $\mathbf{5 0 8}$ & $\mathbf{1 0 0 . 0 0}$ \\
\hline
\end{tabular}

Respondents belonged to various age groups (11-69). The average age of respondents was 36.2 , with a median of 36 . A majority of the respondents are middle-aged. As shown in Table 2 , around $47.8 \%$ of the respondents are between 30 and 39 years old followed by respondents of 40-49 years old whose percentage is nearly $39.8 \%$.

Table 2: Age of Respondents

\begin{tabular}{lrr}
\hline Age & Respondents & Percentage (\%) \\
\hline $11-19$ & 5 & 0.98 \\
$20-29$ & 21 & 4.13 \\
$30-39$ & 243 & 47.83 \\
$40-49$ & 202 & 39.76 \\
$50-59$ & 33 & 6.50 \\
$60-69$ & 4 & 0.79 \\
\hline Total & $\mathbf{5 0 8}$ & $\mathbf{1 0 0 . 0 0}$ \\
\hline
\end{tabular}

Respondents showed a diversity of job sectors, details are reported in Table 3. It is worth noting that around $34.5 \%$ of the respondents work in government jobs and this represents the highest percentage. Almost $21.3 \%$ of respondents work privatesector jobs.

Table 3: Job Sector of Respondents

\begin{tabular}{lrr}
\hline Job Sector & Respondents & Percentage (\%) \\
\hline Public & 175 & 34.45 \\
Private & 108 & 21.26 \\
Self-employment & 93 & 18.31 \\
Others* & 132 & 25.98 \\
\hline Total & $\mathbf{5 0 8}$ & $\mathbf{1 0 0 . 0 0}$ \\
\hline
\end{tabular}

*Housewives, students, retirements and unemployed people

In this study, all the districts in Bilecik were selected. The numbers of respondents by the district are shown in Table 4 Around $40.7 \%$ of the respondents live in Central Bilecik followed by respondents from Bozüyük whose percentage is around $35.0 \%$.

Table 4: District of Respondents

\begin{tabular}{lrr}
\hline Job & Respondents & Percentage (\%) \\
\hline Central Bilecik & 207 & 40.75 \\
Bozüyük & 178 & 35.04 \\
Gölpazarı & 61 & 12.01 \\
Söğüt & 28 & 5.51 \\
Osmaneli & 16 & 3.15 \\
Pazaryeri & 12 & 2.36 \\
Yenipazar & 4 & 0.79 \\
İnhisar & 2 & 0.39 \\
\hline Total & $\mathbf{5 0 8}$ & $\mathbf{1 0 0 . 0 0}$ \\
\hline
\end{tabular}

According to the answers received for the question "Do you think that climate change is happening?" asked in the survey questionnaire, as presented in

Figure 2, around $96 \%$ of respondents (233 male and 256 female) were confident that climate change is occurring. Almost $2.4 \%$ chose one of the "no" and nearly $1.4 \%$ of respondents chose "I don't know".

The result indicated that $88.8 \%$ of the people who were interviewed within the survey think that they thought climate change is also occurring in Bilecik,

Figure 2. There was also a lower proportion of people (around 4.7\%) who believe that climate change is not happening in the city. In Bozüyük, Pazaryeri, Yenipazar and İnhisar over $90 \%$ respondents said climate change is occurring. 


\section{1 - Climate change is occuring}

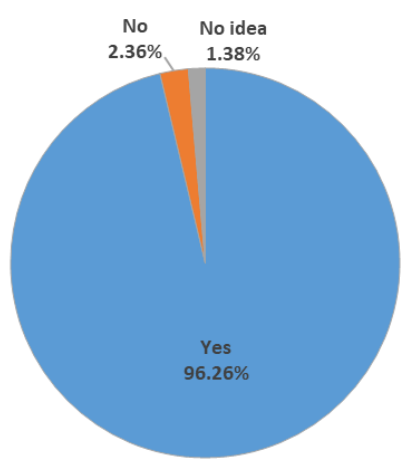

2 - Climate change is occuring in Bilecik

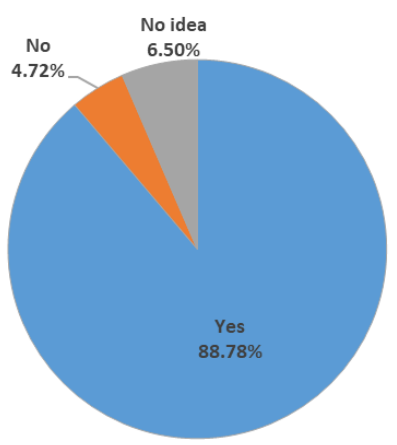

Figure 2: Climate change awareness

According to the answers given to the question concerning the causes of climate change, the increasing number of motor vehicles is at the top of the list $(83.3 \%)$, see
Figure 3. The rapid development of the industry and the destruction of forest and agricultural lands are on the second rank $(81.1 \%)$. Growth of the population ranks as the last (64.6\%) after fossil fuel use for heat and electricity (68.1\%).
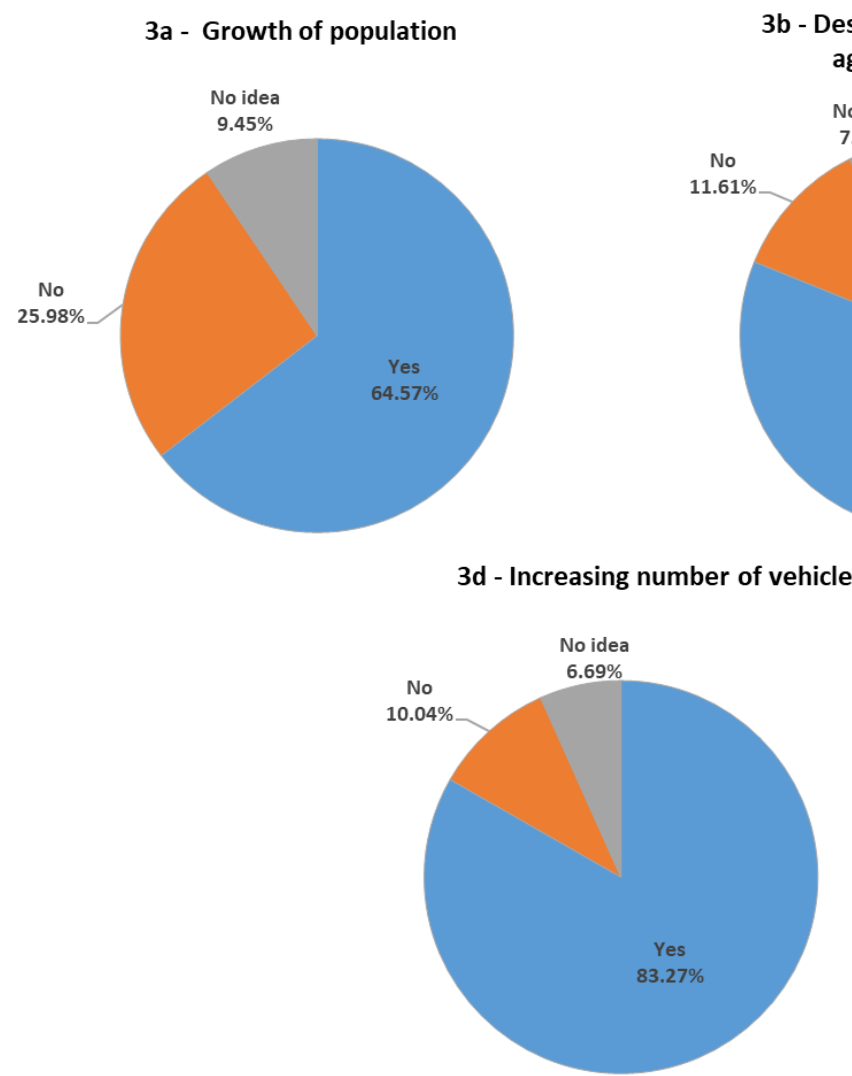

\section{3c - Rapid development of the industry}

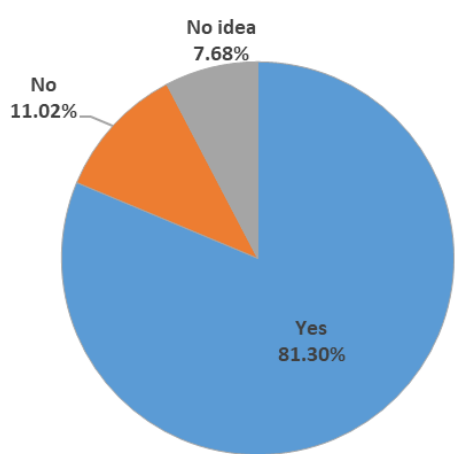

3d - Increasing number of vehicles

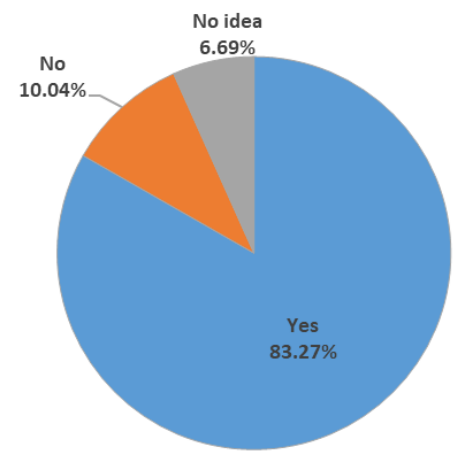

$3 e$ - Fossil fuel use for heat and electricity

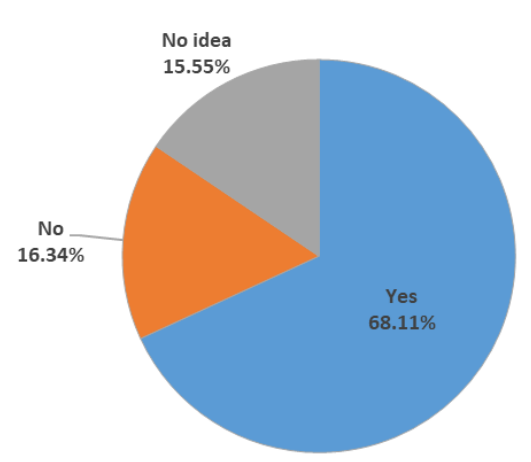

Figure 3: Causes of climate change

According to the answers given for "the effects of climate change", change in climate types (almost 89\%) is the most visible effect of climate change. The increase in fruit and vegetable prices is at the bottom of the list $(76.6 \%)$. 
4a - Floods and hurricanes

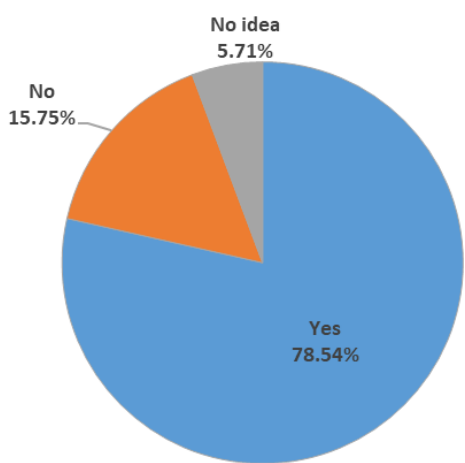

4b - Increase in forest fires

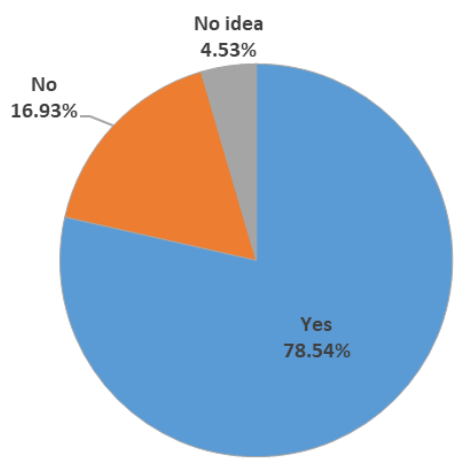

4c - Change in climate types

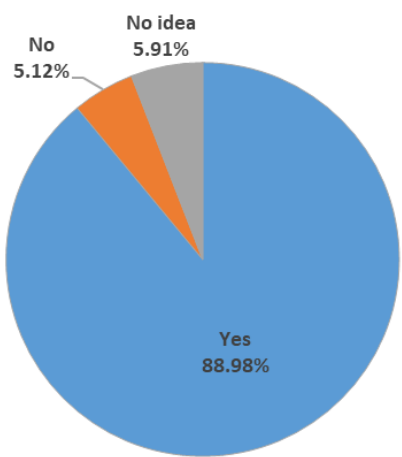

4d - Extinction of some plant and animal species

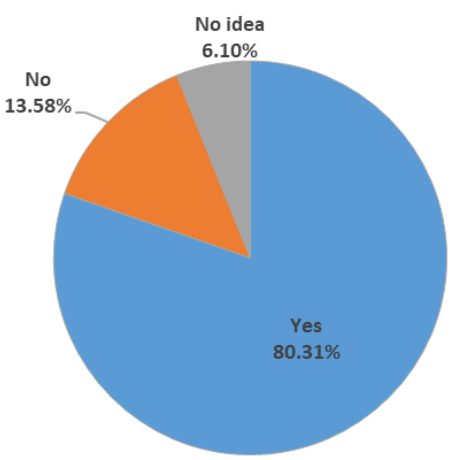

$4 e-$ Increase in vegetable and fruit

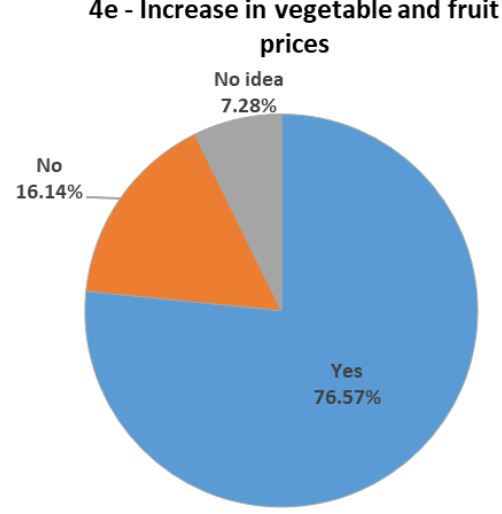

Figure 4: Effects of climate change

As shown in Figure 5, around $87.4 \%$ of the people participating in the survey think that the climate change problem is worrying and threatening while almost $9 \%$ of all respondents

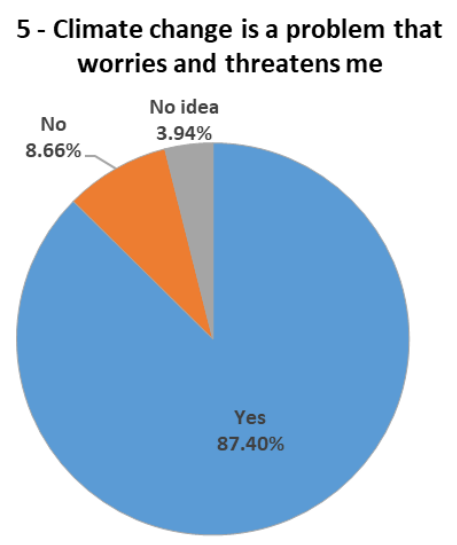

Figure 5: Concern about climate change

In the present survey, nearly $30 \%$ of respondents believe that they act individually against climate change, while around $48.4 \%$ feel that they are not doing enough to tackle climate change, see

Figure 6 . Almost $22 \%$ of the people interviewed in the survey are unable to provide an opinion on whether or not they are doing enough. $53 \%$ of men think that they are not doing enough while $44 \%$ of women feel they are not acting against climate change. did not think global climate change was a threat. Among the respondents, women (89\%) are generally more worried than men $(85 \%)$.

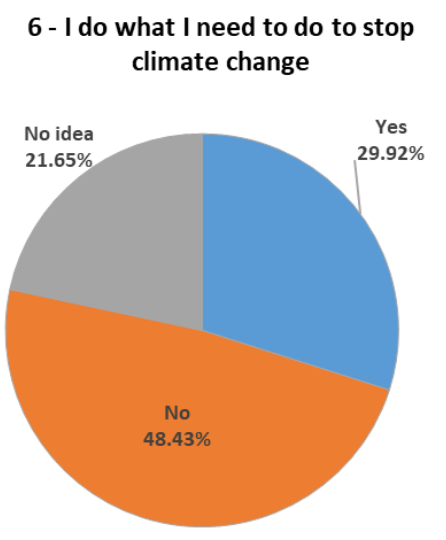

Figure 6: Attitude towards climate change

The survey revealed that there is a need for education on climate change in Bilecik. As presented in Figure 7, around 79.5\% of respondents ( $77 \%$ of male, $82 \%$ of female) think that education on climate change needs to be given to them. 
7 - I need to be educated on climate change

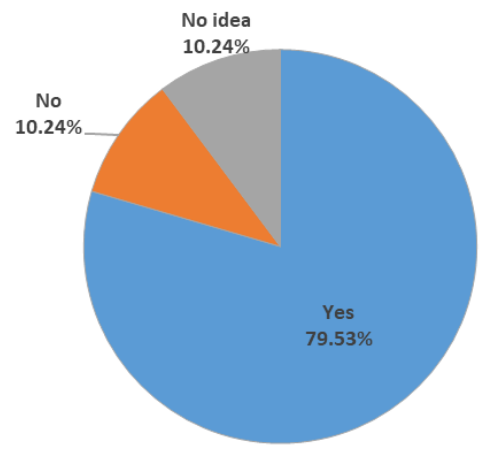

Figure 7: Need for climate change education

\section{Conclusions and Recommendations}

Climate change is one of the major challenges of our time due to its negative effects on human health and ecosystems. The solution to the issue of climate change would need knowledge and comprehension of climate change. In order to accelerate awareness of climate change, it is necessary to understand the level of awareness of people, a problem that is a vital component of long-term policy and planning. Therefore, the objective of this research is to understand public perception and behavior towards climate change.

The data used in this study were generated through a questionnaire survey. A total of 508 (246 males and 262 females) people lives in Bilecik were interviewed. The majority of the respondents were between the ages of 30 to 49 (nearly $88 \%$ ). The results of the survey were evaluated, and the opinions of the respondents were determined.

According to research findings, $96 \%$ of respondents said that they believe that climate change is occurring, $89 \%$ state that climate change is occurring in Bilecik, and $87 \%$ of respondents believe that climate change is threatening. The majority of respondents $(83 \%)$ believe that increasing the number of vehicles is the primary cause of climate change, while climate change $(89 \%)$ is the most obvious cause. Results have shown that at least 87 of every 100 people in Bilecik are concerned about climate change. Women were more worried about climate change than men.

According to the results, it was observed that the problem of climate change was accepted at the local level and the concern on climate change is high and they wanted to get more education on this subject.

Given that climate change is a major threat, it is helpful to determine the level of knowledge and awareness at the local level, in particular on the causes, effects, how to address the issue, and adaptation. The results of the paper would help to better design and communicate future climate change-related activities. Education is the first line of defense to spread awareness and begin to impact people's behavior and attitudes towards climate change. Raising awareness of climate change at the local level is important as the impacts of climate change exacerbate the frequency and extent of disasters.

\section{Acknowledge}

This work was supported by the European Union through the "Better Futures with Enhanced Capacity and Awareness on Climate Change" Project [TR2013/0327.05.01-02/113] as part of e-ISSN: 2148-2683 the "Capacity Building in the Field of Climate Change in Turkey Grant Scheme."

\section{References}

Allen, M. R., O.P. Dube, W. Solecki, F. Aragón-Durand, W. Cramer, S. Humphreys, M. Kainuma, J. Kala, N. Mahowald, Y. Mulugetta, R. Perez, M. Wairiu, and K. Zickfeld. (2018). Global Warming of $1.5^{\circ} \mathrm{C}$. An IPCC Special Report on the impacts of global warming of $1.5^{\circ} \mathrm{C}$ above pre-industrial levels and related global greenhouse gas emission pathways, in the context of strengthening the global response to the threat of climate, change, sustainable development, and efforts to eradicate poverty. Geneva, Switzerland.

BEBKA. (2018). Bilecik Illi Mekansal Strateji Planı Raporu. Retrieved 01.03.2021 from

https://www.bebka.org.tr/admin/datas/yayins/213/bilecik-ilimekansal-strateji-plani-raporu 1571052398.pdf

Cramer W, G. J., Fader M, Garrabou J, Gattuso J-P, Iglesias A, Lange MA, Lionello P, Lla-sat MC, Paz S, Peñuelas J, Snoussi M, Toreti A, Tsimplis MN, Xoplaki E. (2018). Risks associated to climate and environmental changes in the Mediterranean region. Nature Climate Change 8, 972-980, https://doi: 10.1038/ s41558-018-0299-2

Dal, B., Öztürk, N., Alper, U., Sonmez, D., \& Çökelez, A. (2015). An Analysis of the Teachers' Climate Change Awareness. Athens Journal of Education, 2, 111-122. https://doi.org/10.30958/aje.2-2-2

Glasgow, L., Langaigne, B., Thomas, C., Harvey, O., \& Campbell, E. (2018). Public Knowledge and Attitudes towards Climate Change and Its Impacts on Ecosystems in Grenada. American Journal of Climate Change, 07, 600-610. https://doi.org/10.4236/ajcc.2018.74037

Governorate of Bilecik. (2020). Bilecik. Retrieved 12.11.2020 from http://www.bilecik.gov.tr/

Kabir, M. I., Rahman, M. B., Smith, W., Lusha, M. A. F., Azim, S., \& Milton, A. H. (2016). Knowledge and perception about climate change and human health: findings from a baseline survey among vulnerable communities in Bangladesh. BMC Public Health, 16(1), 266. https://doi.org/10.1186/s12889-016-2930-3

Kim, M. J., \& Hall, C. (2019). Can Climate Change Awareness Predict Pro-Environmental Practices in Restaurants? Comparing High and Low Dining Expenditure. Sustainability, 11, 6777. https://doi.org/10.3390/su11236777

Lee, T. M., Markowitz, E. M., Howe, P. D., Ko, C.-Y., \& Leiserowitz, A. (2015). Predictors of public climate change awareness and risk perception around the world. Nature Climate Change, 5(11), 10141020. https://doi.org/10.1038/nclimate2728

Marshall, N. A., Park, S., Howden, S. M., Dowd, A. B., \& Jakku, E. S. (2013). Climate change awareness is associated with enhanced adaptive capacity. Agricultural Systems, 117, 30-34. https://doi.org/https://doi.org/10.1016/j.agsy.2013.01.003

MoEU. (2012). Are We Aware of Climate Change? Publication of the Preparing Turkey's 2nd National Communication on Climate Change Project. T.R. Ministry of Environment and Urbanization General Directorate of Environmental Management, Department of Climate Change. Ankara, Turkey.

MoEU. (2018). $7^{\text {th }}$ National Communication of Turkey, Republic of Turkey Ministry of Environment and Urbanization, General Directorate of Environmental Management, Department of Climate Change. Ankara, Turkey.

TURKSTAT. (2020). Provinces of Turkey by population. Retrieved 15.11.2020 from

https://ata.tuik.gov.tr/Kategori/GetKategori?p=nufus-vedemografi-109\&dil=2

UN. (2020). United Nations Climate Change Annual Report 2019. United Nations, Climate Change. Bonn, Germany.

UNFCCC. (1992). United Nations Framework Convention on Climate Change. Retrieved 12.11.2020 from https://unfccc.int/resource/docs/convkp/conveng.pdf 